\title{
First and Second Phase of Human Centered Design Method in Design of Exterior Seating Furniture
}

\section{Prve dvije faze dizajniranja vanjskog namještaja primjenom metode dizajna usmjerene prema korisniku}

\author{
Original scientific paper • Izvorni znanstveni rad \\ Received-prispjelo: 11. 1. 2021. \\ Accepted-prihvaćeno: 26. 5. 2021. \\ UDK: $630 * 836.1$ \\ https://doi.org/10.5552/drvind.2021.2101
}

\begin{abstract}
The article describes a part of the designing process of exterior furniture that utilizes HPL (high pressure laminate) with the reduced use of construction metal elements, using user-centered design methods. The process is divided into several phases. This article primarily uses human-centered design and describes the process of researching user attitudes and market research, as important methods in the overall design process. The observed results are crucial especially when introducing new products based on products already existing on the market. The contemporary market is filled up with a surplus of products that are not so customer-oriented, and customers are often lost in their choice. Currently, there is a tendency on the market to personalize each product to the customer, so this becomes one of the main designer's methods in designing a product. The designer can personalize a product based on the user and market research. New products can be different in the approach to customer's needs and attitudes in cases that the designing process follows the current needs. Also, it is important to present it properly to the public. It is necessary to create a representative customer, who can represent the potential group. This young woman has specific characteristics that can be used in the rest of the designing process - her relationship with nature and sitting outdoors, her relationship with furniture and her ability to purchase a new product.
\end{abstract}

Keywords: exterior furniture; human centered design; wood; user research; market research; furniture design

SAŽETAK • U članku se opisuje dio postupka projektiranja vanjskog namještaja za koji se iskorištava HPL (visokotlačni laminat), uz smanjenu upotrebu metalnih građevnih elemenata $i$ uz primjenu metode dizajna usmjerene prema korisniku. Proces je podijeljen na nekoliko faza. U ovom je radu težište na dizajnu podređenom čovjeku, pri čemu se opisuje i postupak istraživanja stajališta korisnika i istraživanje tržišta kao važne metode u cjelokupnom procesu dizajniranja. Uočeni su rezultati presudni za uvođenje novih proizvoda utemeljenih na već postojećim proizvodima na tržištu. Suvremeno je tržište preplavljeno proizvodima koji nisu osobito orijentirani prema kupcu, a kupci se pri izboru često gube u tom mnoštvu ponude. Trenutačno je na tržištu zamjetna težnja da se svaki proizvod prilagodi kupcu, pa to postaje jedno od glavnih dizajnerskih polazišta pri dizajniranju proizvoda. Zahvaljujući istraživanju tržišta i zahtjeva korisnika, dizajner može prilagoditi proizvod svakom pojedinom kupcu. Također, sve je više dokaza da se konkurentnost nekih tvrtki temelji na inovativnoj upotrebi dizajna usmjerenoga

\footnotetext{
Authors are PhD student and professors at Faculty of Forestry and Wood Technology, Mendel University in Brno, Brno, Czech Republic.

${ }^{2}$ Author is associate professor at University of Zagreb, Faculty of Forestry and Wood Technology, Institute of Furniture and Wood in Construction, Zagreb, Croatia.
} 
prema korisniku. Ako postupak dizajniranja prati trenutačne potrebe i ako se pravilno prezentira u javnosti, novi se proizvodi mogu razlikovati po pristupu potrebama i stajalištima svakog kupca.

Ključne riječi: vanjski namještaj; dizajn usmjeren prema čovjeku; drvo; istraživanje zahtjeva korisnika; istraživanje tržišta; dizajn namještaja

\section{INTRODUCTION 1. UVOD}

From the outside perspectives, it is often difficult to fully understand how exterior (or site) design integrates the elements of furniture that are used for various design purposes and create a sense of place. Such an understanding can open up creative possibilities for designers of outdoor areas and enable them to shape spaces that can succeed in achieving their aims over the long term (Yücel, 2013). Also, there is growing evidence that the competitiveness of some companies is based on an innovative use of user-oriented design (Montresor and Vezzani, 2019).

Today's customers prefer to sit outside, in the parks, outdoor public spaces or in the gardens and on terraces. These habits are the main reasons for using special materials and special types of technologies together with new design methods during the product production.

While designing, it is necessary to investigate all aspects that influence the acceptance of new product innovations (Mulder-Nijkamp, 2020). It is also always important to do research in the public, because the people are the ones who are going to use the final product and it should always serve its user (Parsons, 2009).

Previous results show that the most common material for exterior furniture is wood in combination with a metal supportive structure (Vuković, 2018). Using solid wood helps the design of exterior furniture to develop in more imaginative and user-friendly ways, but it brings further technical problems in joining two different materials (Fictum et al., 2018). The goal of this study is to make the first two parts of the human centered design process of a bench according to the Czech Technical Standards (WEB 1). These parts are made by using High Pressure Laminate (HPL) in combination with solid wood, while reducing the use of metal fasteners. This article focuses on user-centered design methodology, which uses user and market research as the main design methods that lead to creating the imagined user the "Persona". The research was carried out in 2017 with the aim of designing a new product for today's customer. The obtained data from the user research was implemented into the designing process. The user research was made by HCD (Human Centered Design) principles in the first part - Empathy. This phase of research is often a neglected part of design, but it is an important source of information for each designer.

HPL and solid wood were chosen as the main materials mostly due to their good properties for their intended use. In addition, the Ready-to-Assemble (RTA) furniture principles were used in the project. This approach makes transport of the furniture easier and more efficient, reduces the price of logistics and overall saves money to our potential customer. Also, it was decided that the exterior seating furniture would be designed for a private owner and not as seating for open urban spaces.

\subsection{Human centered design}

\subsection{Dizajn usmjeren prema čovjeku}

In the recent years, entrepreneurship has become a popular topic and has attracted many young people to start their own companies. In entrepreneurship, design is generally viewed as essential to innovation, replacing the conventional role of the engineer (Xihui and Rieple, 2019), and Human-Centered Design (HCD) is one of the unavoidable design methodologies.

Human-Centered Design, (in the market research phases called User-Centered Design) is a set of principles used during formation of a product, its related services and surrounding environment that also includes the organization and the interactions between the product and its intended user. The reason for its name is that the whole process starts and ends with people. These techniques are based on the behavior and needs of a person (Norman, 2010), because the idea of sustained development cannot be effectively implemented without including social needs and people-oriented designing (Rzeszotarska-Palka and Czalczynska-Podolska, 2019). Users attempt to meet their unfulfilled needs by designing and developing new products and processes (in open design platforms and due to the digital fabrication technologies like 3D printing) and thus provide new concepts and design ideas (Naik et al., 2020).

In this project, some techniques of HCD were used. Its first step is the necessity to respect the opinions and attitudes of the people. Thus, the whole research is conditioned by empathy toward the customer (Weinschenk, 2012). The next step is to create. This crucial part is the most well-known phase during the designer's work. This phase is not just about sketching or modeling; the team creates charts, a two-axis matrix and diagrams. After creating, the product has to be realized. Product designer uses models, prototypes, scale models, virtual models or part-models (Fernandes et al., 2017). In this part, it is necessary to create a timeline. In the end, it is important to let users evaluate the resulting product. This evaluative research serves as a feedback and helps to address issues of the product design (Creative Commons, 2013).

\section{MATERIALS AND METHODS}

\section{MATERIJALI I METODE}

\subsection{Design process}

2.1. Proces dizajna

Designers' practices have been constantly evolving in the last two centuries. During the last decades new technologies, processes and approaches have in- 
fluenced them (Menichinelli et al., 2020). That is the reason why there are many processes of design in the world now. Nevertheless, the HCD is considered as the most useful in today's society (as part of the Design Thinking Theory). Design Thinking leverages the body of design theory literature and adapts it to interpret how design-driven innovation can happen in the context of business (Verganti et al., 2020). Its principles were created by Creative Commons (2013) and published by IDEO organization, IDE organization, Heifer International and ICRW organization: "Design focused on human". The process is divided into three steps: Listening, Creation, and Realization. These steps are very comprehensive. This process was modified into fivestep process as a result of the needs of modern design: Empathy, Define, Ideation, Prototyping, Testing.

Design Thinking (also HCD) supports the mindset of co-creation pedagogy as both their key characteristics and methods arise from equal, multidisciplinary co-creation and person-centered approaches (Jussila et al., 2020).

\subsection{User research}

2.2. Istraživanje mišljenja korisnika

The research of user's opinion, attitudes and needs can fall either into the first or second step: Empathy and Define. The empathy is necessary during the design process because, if someone wants to design a new product, it is not sufficient to create just a "good product". A designer has to know his/her possible client, or at least to imagine his/her profile. The client determines the success rate of a new product in a market and the designer needs to know the users (Weinschenk, 2012).

Quantitative exploratory metrics were used to collect the necessary data. Due to the envisaged product, it was necessary to obtain larger and reliable data. For this purpose, individual e-questionnaires were used. The assumed hypothesis of this executed research was that people actively use their exterior furniture (whether in their private or in public spaces) and that they prefer the materials chosen for the new product. After the research was done, the resulting data were evaluated, and the "Persona" was created.

In the user research, a lot of data regarding our respondents were collected. Respondents were also potential users and buyers. After the data evaluation, a profile of the "Persona" was created, which facilitated the process of designing a new product for exterior use - namely the bench.

\section{Basic Survey Information}

There were 127 respondents for the study research. The respondents were randomly selected, so that the questionnaire results would remain unbiased and impartial. The user research was divided into six blocks:

1. Personal information

2. Questions about spending their time in exterior

3. Used outdoor furniture material

4. Customers own outdoor furniture

5. Purchase of a new exterior furniture

6. RTA principles
There were series of questions associated with each block. The questionnaire was developed by the team of authors and it was shared online through social networks, so the sample of people who can answer the questions or the answer rate could not be counted. In this part of the study, quantitative exploration type of investigation was used. In the questionnaire, the potential user was asked several types of questions - open answers, single choice answers and multiple-choice answer. A basic statistical method was used for analyzing the results obtained. Arithmetic mean and user sets were used. Nominal and ordinal values were monitored, as well as rations. All data were processed in Microsoft Excel.

Due to the type of sharing the questionnaire, people at the age of $65+$ were not in the focus group. Seniors have needs other than the focus group and that is why they need other specific properties of furniture.

\subsection{Market research \\ 2.3. Istraživanje tržišta}

Five companies were chosen as the example of the selected type of furniture in 2018 (before the designing started). The main indicators of the chosen type of furniture were: use of RTA principles, materials and technology of exterior furniture. The team of authors described here primarily worked with online data resources of companies from Europe and USA.

\section{RESULTS}

\section{REZULTATI}

3.1 User research results (Empathy)

3.1. Rezultati istraživanja korisnika (empatija)

\section{Block 1: Personal information}

This section of user research serves to create a Persona and to segment customers into different categories - market segregation.

The group of respondents contained $68 \%$ of women and $32 \%$ of men. Age diffusion is shown in Figure 1.

The research revealed that the respondents had predominantly secondary education and their average gross monthly wage was up to CZK 15,000 (about 642 Euros).

The question regarding the transport showed that the connection between the time spent outside (to possibly use exterior furniture) and the type of transport was verified. It was discovered that people who use public transport and bicycles have more opportunities to spend their time outdoor and therefore use outdoor furniture more frequently. More than half of our respondents (55.2\%) mainly used public transport, 28.8 $\%$ used a car and $14.4 \%$ most often just walked. The bicycle as a mean of transport was used by only $1.6 \%$ of respondents.

The last question divided the respondents according to their interests. More than $60 \%$ of respondents said that their main interests included watching movies, hiking and traveling. 

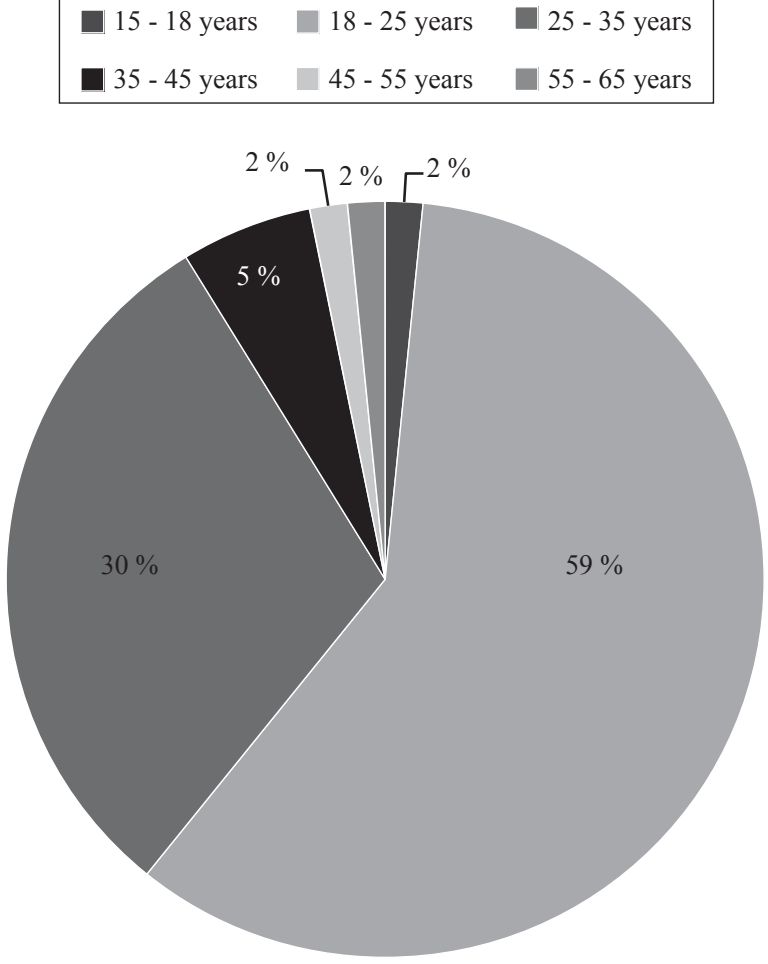

Figure 1 Age of respondents

Slika 1. Dob ispitanika

Block 2: Questions about spending time in exterior

Most respondents $(85.6 \%)$ spent their time outdoors mostly hiking and walking. The second favorite places of interests are outdoor restaurants and bars with $55.2 \%$. The last significant group of $48.8 \%$ is made of respondents who do outdoor sport.

Respondents mostly use their own exterior furniture $(41 \%) .38 \%$ of respondents mostly use the exterior furniture in bars and restaurants.
Block 3: Used outdoor furniture

The goal of this section was to find out whether the used material made impact on the overall popularity of the product, namely if the users were more enticed to sit on the furniture and use it. Also, the section describes defects or deficiencies that the users have noticed with this furniture. According to the research results, it is clear that the used material is an important factor $-59 \%$ of respondents said that this factor was meaningful. It is justified by hygiene and comfort - in the winter. The user does not want to use metal furniture or furniture that can spoil the user clothes.

The most common defects found by respondents were table instability and the inconvenience of singleseat sitting. See Figure 2 for more details.

The preferred furniture appearance was the natural appearance (the exposed material) as indicated in 56.5 $\%$ of user's responses. In $41.9 \%$ of responses, neutral colors were preferred. Only in $1.6 \%$ of cases respondents preferred an over dimensioned look. As for the preferences according to the material, the most popular material used was solid wood (73\% of responses). The second place was taken by a combination of wood and metal materials ( $65.3 \%$ of responses).

\section{Block 4: User's own exterior furniture}

Only $66.4 \%$ of respondents had their own exterior furniture. This question block was only filled by $65.3 \%$ of respondents due to this limitation.

According to Figure 3, it was found out that the majority of respondents owned a complete outdoor set (table and several chairs) or only a chair or a bench.

According to the research carried out, the exterior furniture was placed mainly in the garden, $51 \%$ of respondents. $43 \%$ of respondents said that their furniture was placed on their terrace or balcony.

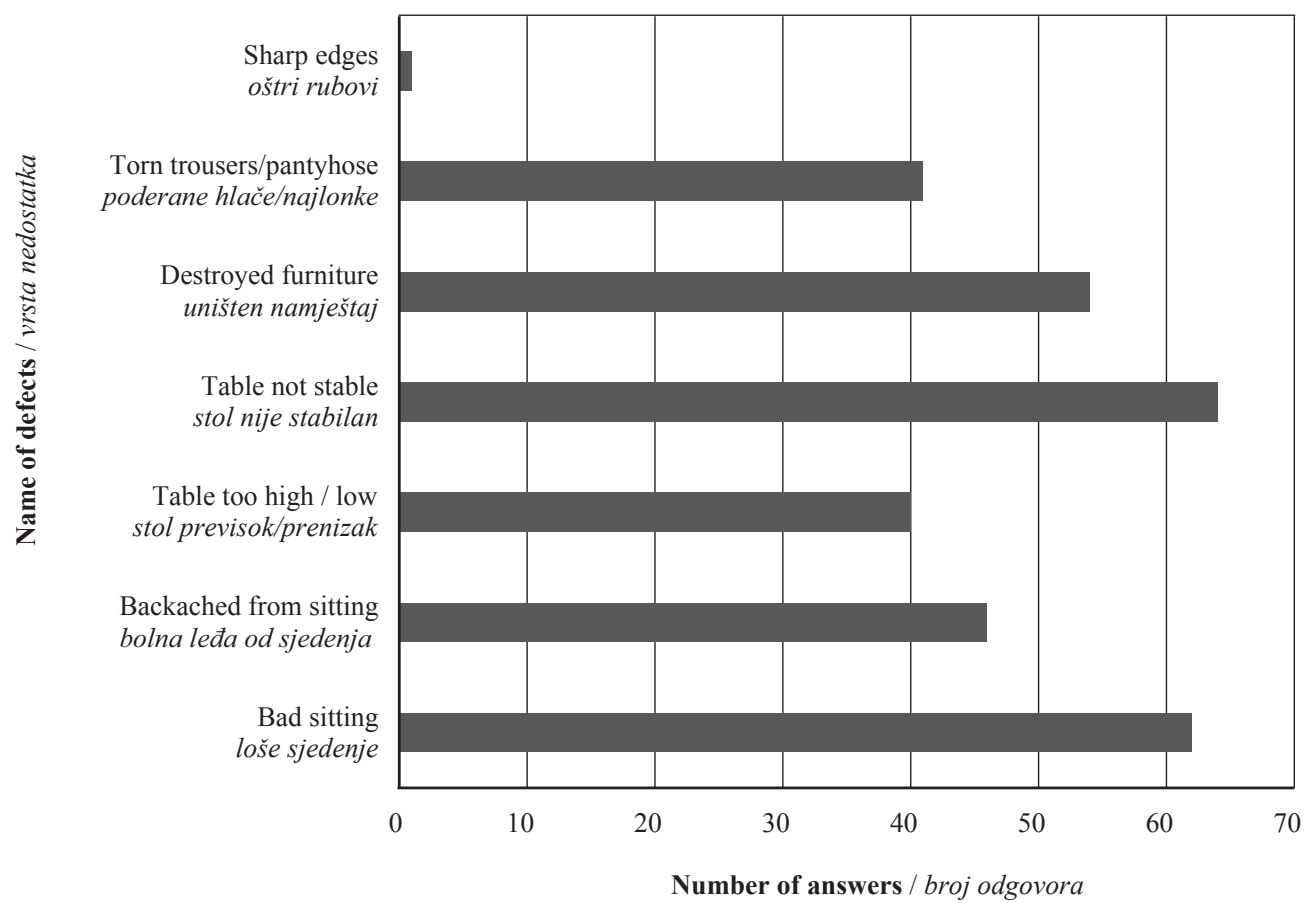

Figure 2 Most common defects of exterior furniture Slika 2. Najčešći nedostatci namještaja 


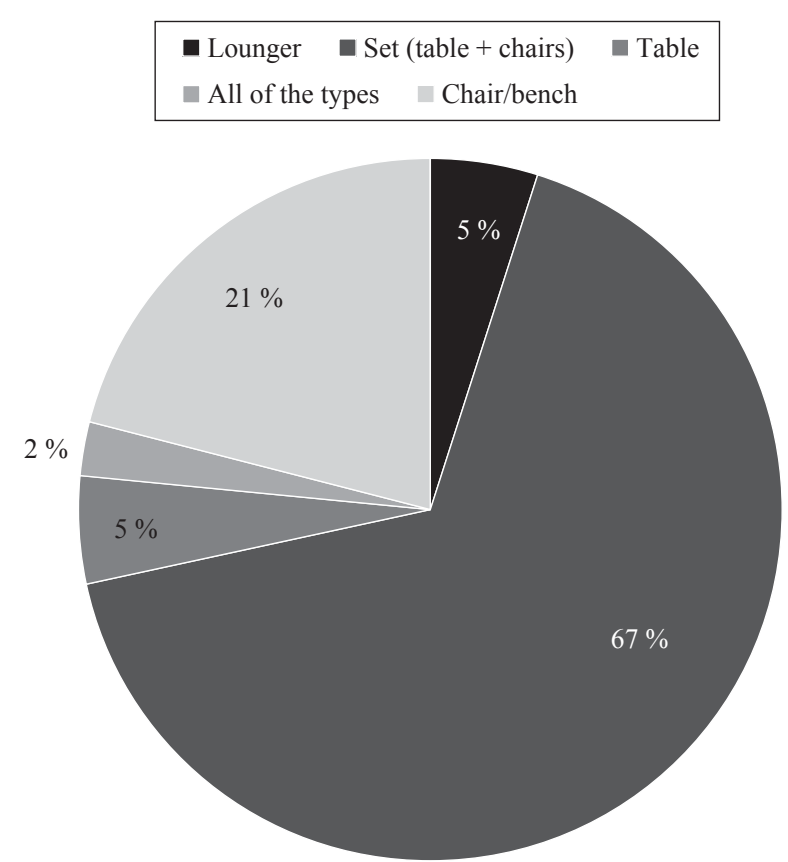

Figure 3 User's own exterior furniture

Slika 3. Korisnikov postojeći vanjski namještaj

All $84.3 \%$ respondents were satisfied with their own furniture. The most common reason for user's dissatisfaction was the furniture age.

Block 5: Purchase of new design furniture

The first question of this block was the most important feature of user's new furniture products. The furniture functionality was selected as the most important feature (with $43.3 \%$ of responses), see Figure 4.
Answers to the question of how much money users are willing to pay for a new chair were scattered. One third of answers fell into a category of $500-1$, $000 \mathrm{CZK}$ (22 - 46 Euros) per chair, which is the largest part of the answers.

The most popular choice was a hobby market, in $28.7 \%$ of responses. According to the respondents, the second place was taken by IKEA. Our respondents buy furniture roughly once in five years.

\section{Block 6: RTA Principles}

According to the research results, $76.8 \%$ of respondents preferred to buy demountable furniture, where customers assemble the furniture by themselves. At the same time, $94.4 \%$ of respondents did not find assembly of the furniture complicated. Assembly instructions were found to be understandable enough by $3 / 4$ of respondents. Unfortunately, more than half of respondents did not care about this type of furniture and did not tighten joints, even if this was stated in the assembly instructions.

\subsection{The Persona (Define) \\ 3.2. Osoba (definiranje)}

This part of the process is an integral part of the design process. Persona shows the average user/customer and helps the final design. A designer always tries to help with the design for a specific person. The created Persona is based on the first part of this study: the user research. In order to create an imaginary person's profile, it is necessary to think of some missing information - this information cannot be obtained from our respondents: especially the name.

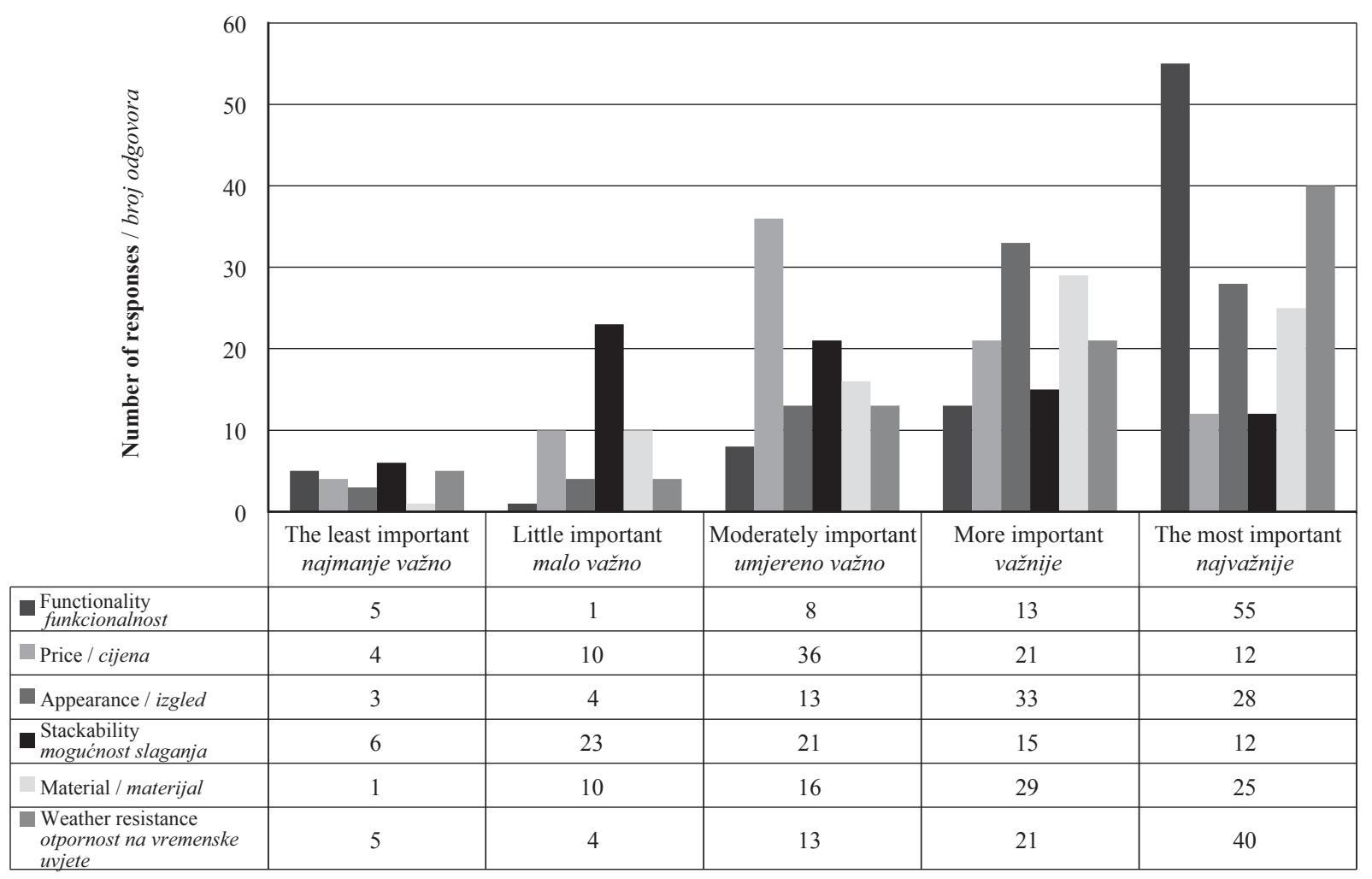

Figure 4 Features of new furniture according to its importance for users

Slika 4. Obilježja novog namještaja prema njihovoj važnosti za korisnike 
Table 1 The Persona - Helena Valesova

Tablica 1. Osoba - Helena Valesova

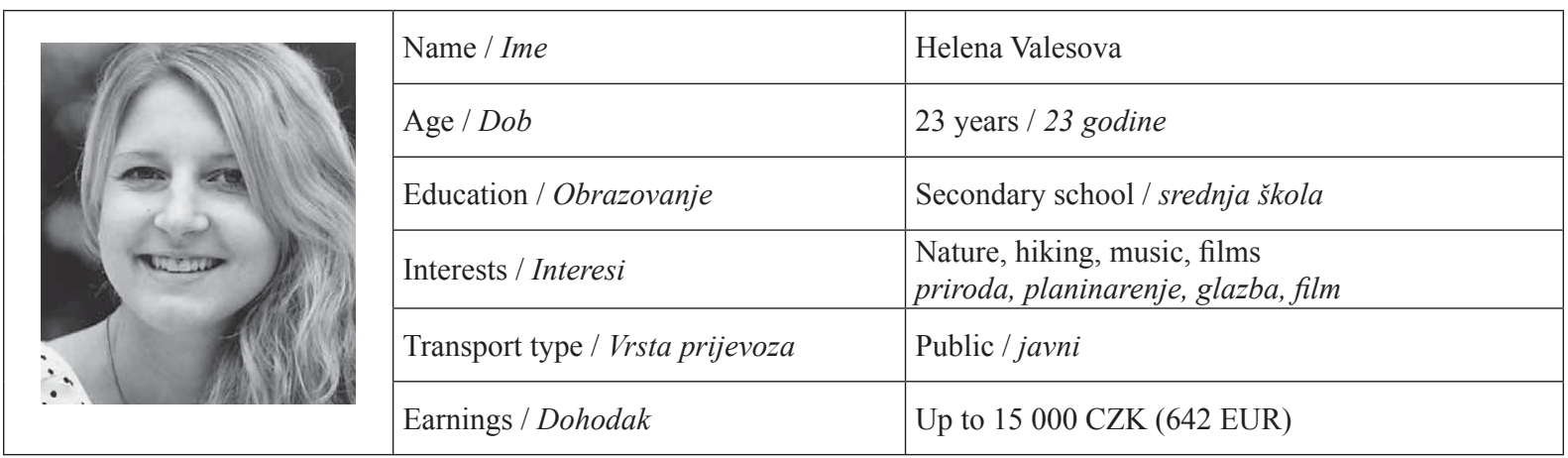

Helena spends most of her time outdoors hiking and walking, or in outdoor bars and restaurants. Helena uses her own outdoor furniture or furniture in restaurants. The material used for furniture influences Helena. She prefers wooden furniture or a combination of wood and metal. Helena's biggest problem during her use of exterior furniture was her back aching while sitting on the furniture and instability of her table.

Helena has her own exterior furniture, namely she owns a set of chairs and a table. She is satisfied with her furniture and she placed it in her garden.

When Helena is buying her new exterior furniture, the most important features are furniture functionality and its weather resistance. She will probably buy these new products in a hobby market or similar stores and she is willing to spend in the range of 500-1500 CZK per one chair. Helena buys new furniture once in 5 years.

Helena likes to assemble her new furniture and its assembly is not a complication for her. At the same time, installation instructions do not seem to be complicated or confusing either. Regrettably, she does not tighten up the furniture joints on a regular basis.
For clarity, a summary in Table 2 is provided.

\subsection{Market research results}

\subsection{Rezultati istraživanja tržišta}

Products in the market research were selected based on the data obtained in the user research. Each example corresponds to at least one of the requirements by the Persona.

\section{Request: RTA principle}

A sample product used for sitting was manufactured by Semigoods Company (WEB 2). Designers used High Pressure Laminate as a construction material on all sides of the chair and they added solid wood as a natural and interesting element of the product. They found that the properties of solid wood and HPL were very good - strong and durable. However, solid wood was more suitable for the contact with the human body due to better thermal insulation.

This company used metal elements to join all parts of the product, but this product was chosen due to the design. It complied with the RTA principles, but it

Table 2 Summary table

Tablica 2. Zbirna tablica

\begin{tabular}{|c|c|c|}
\hline $\begin{array}{l}\text { Characteristic of Helena / } \\
\text { Helenine karakteristike }\end{array}$ & $\begin{array}{l}\text { Her relationship with outside } \\
\text { furniture / Njezin odnos prema } \\
\text { vanjskom namještaju }\end{array}$ & $\begin{array}{l}\text { - the used material influences Helena - she prefers } \\
\text { wood and metal / Heleni je važan materijal od } \\
\text { kojega je namještaj izrađen-ona više voli drvo } i \\
\text { metal } \\
\text { - she used outside furniture from bars or restaurants } \\
\text { and her own / Helena se koristila vanjskim } \\
\text { namještajem u barovima ili restoranima } i \text { vlastitim } \\
\text { - the biggest problem during using for her is } \\
\text { uncomfortable sitting / najveći problem tijekom } \\
\text { uporabe za Helenu je neudobno sjedenje }\end{array}$ \\
\hline $\begin{array}{l}\text { Her own furniture / Helenin } \\
\text { vlastiti namještaj }\end{array}$ & In the garden / Vrtni namještaj & Set of chairs and table / garnitura stolica i stolova \\
\hline \multirow{3}{*}{$\begin{array}{l}\text { Buying new outside furniture / } \\
\text { Kupnja novoga vanjskog } \\
\text { namještaja }\end{array}$} & $\begin{array}{l}\text { The most important factors / } \\
\text { Najvažnija obilježja }\end{array}$ & $\begin{array}{l}\text { - weather resistance / otpornost na vodu } \\
\text { - functionality / funkcionalnost }\end{array}$ \\
\hline & $\begin{array}{l}\text { Where will she buy? / Gdje će ga } \\
\text { kupiti? }\end{array}$ & Hobby (or similar) stores / Hobi ili slične trgovine \\
\hline & $\begin{array}{l}\text { How much will she spend? / } \\
\text { Koliko će novca potrošiti? }\end{array}$ & $500-1500$ CZK (147 - 440 HRK) \\
\hline \multirow[t]{2}{*}{ RTA principle / RTA načelo } & Does she like it? / Sviđa li joj se? & $\begin{array}{l}\text { Yes, instructions are not complicated / da, upute } \\
\text { nisu složene }\end{array}$ \\
\hline & $\begin{array}{l}\text { Does she care about joins? / Je li } \\
\text { joj važan način sastavljanja? }\end{array}$ & No / ne \\
\hline
\end{tabular}




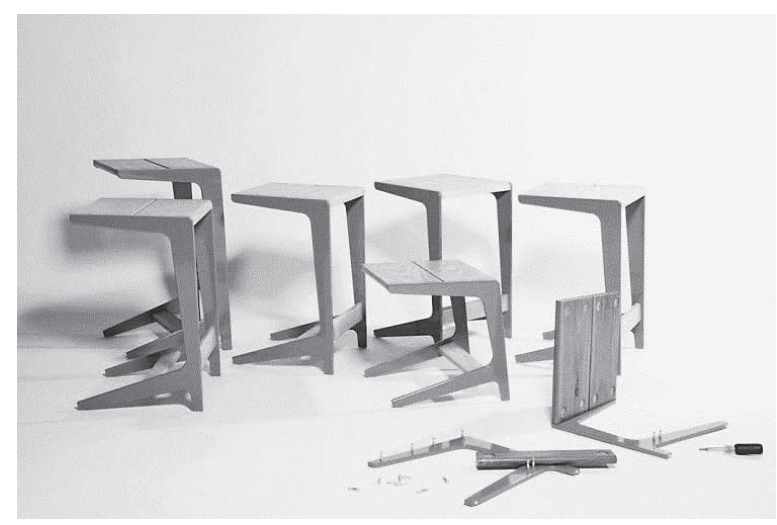

Figure 5 One of the chosen products due to RTA principles used, design by Semigoods Company (WEB 2)

Slika 5. Jedan od proizvoda odabranih zbog primijenjenog RTA načela; dizajn Semigoods (WEB 2)

did not meet the requirements of the persona due to its price - the bench cost was 1500 Euros.

Request: Functionality, stackability, comfortable sitting, weather resistance

Chairs Bohem are a collection made by mmCité Company (WEB 3), designed by Aleš Kachlík. The designer created retro style sitting with the aim of providing comfortable sitting. The chair is made of galvanized power-coated steel structure. The seats and backrests are made of sheet aluminium or plywood. The chair is available in two heights. All of the products from this collection are fully stackable.

The next example is bench Arki-Bench. This product was made by Pedrali Company. It was chosen due to the material used - the seating part is made of HPL, the rest of the product is made of massive wood.

\section{DISCUSSION CONCLUSIONS}

\section{RASPRAVA I ZAKLJUČAK}

The HCD principles have brought the necessary information for the design process. The information gained from users was necessary to determine the final

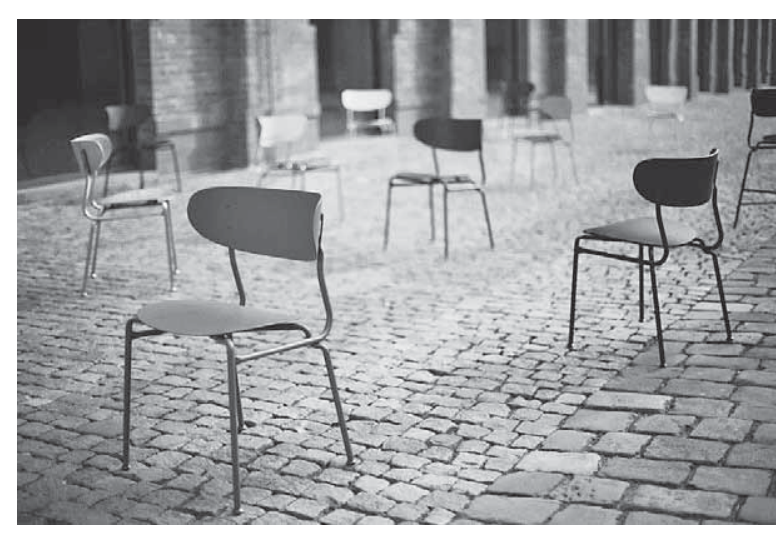

Figure 6 Collection Bohem by mmCité, chosen due to functionality, comfortable sitting and stackability (WEB 3) Slika 6. Kolekcija Bohem tvrtke mmCité odabrana zbog funkcionalnosti, udobnog sjedenja i lakoće sastavljanja (WEB 3)

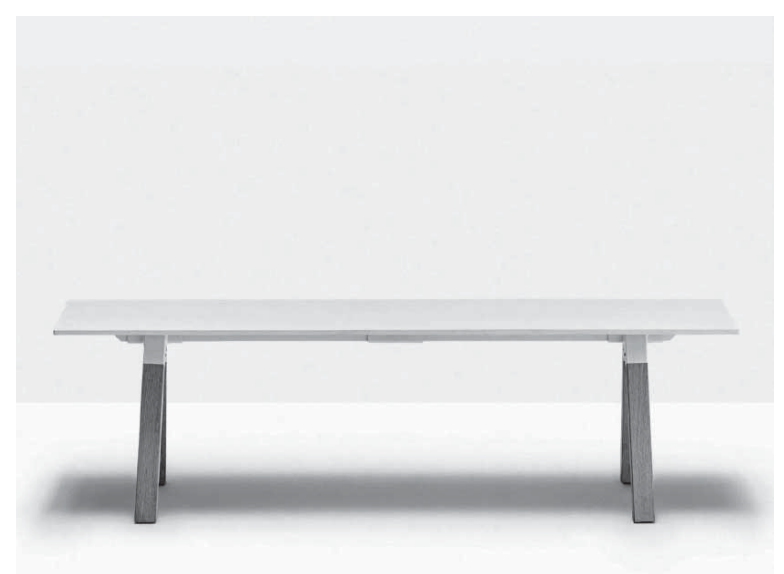

Figure 7 Bench Arki-Bench by Pedrali, chosen due to used HPL material (WEB 4)

Slika 7. Klupa Arki-Bench tvrtke Pedrali izabrana zbog upotrijebljenog HPL materijala (WEB 4)

design for the new products - outdoor bench made of HPL. Everything discovered during the user and market research was incorporated during the whole design process. The number of respondents was sufficient in order to get a complete picture of the situation. With this type of questions, the designer would better understand the specific requirements and preferences of potential users.

During the market research, it was found out that some products with a few of the used principles (e.g. RTA) already exist; however, a product combining all of the principles used within this project was not recognized.

The results of the user research showed that today's customer wants to buy a new functional and weather resistant exterior furniture in a hobby market or similar store. The customer will spend about $22-40$ Euros per one chair and he/she will buy a new product every five years. If the assembling is not complicated, the customer prefers to assemble his/her new furniture. According to the user research, it would be better to design products where it is not necessary to tighten up the furniture joints on a regular basis, because most of respondents said that they do not do it regularly.

The market research showed that there are many different uses of HPL, RTA principles or minimization of metal elements in furniture, but the used combination of the above materials was not found. The biggest challenge of the designing process will be to meet all the requirements while respecting the price range. No matching products were found at the requested price. The price was determined on the basis of the user research so it depends on the chosen group.

The new product will be a bench or sitting chair made of a combination of materials in natural colors no specific colorful surfaces. For the user, the price and functionality of the product is very important, and the biggest problem while sitting on the chairs is users' backache.

All the data will be used in the designing process of a new product for exterior use - innovative design bench oriented to the user. 


\section{REFERENCES}

\section{LITERATURA}

1. Creative Commons, 2013: HCD design zaměřený na člověka: soubor nástrojů (online), $2^{\text {nd }} \mathrm{ed}$. Brno, Flow., pp. 1-200. https://web2.mlp.cz/koweb/00/04/23/36/59/hcddesign-zamereny-na-cloveka.pdf (Accessed Feb. 20, 2019).

2. Fernandes, P. T.; Canciglieri, O.; Oliveira Santanna, A. M., 2017: Method for integrated product development oriented to sustainability. Clean Technologies and Environmental Policy, 19: 775-793.

https://doi.org/10.1007/s10098-016-1265-1.

3. Fictum, L.; Hrabec, M.; Šimek, M.; Szökeová, S.; Sobotková, A.; Domljan, D., 2018: Design of exterior furniture from high pressure laminate. In: Proceedings of $29^{\text {th }} \mathrm{In}$ ternational Conference on Wood Science and Technology (ICWST): Implementation of wood science in woodworking sector, Župčić, I., Španić, N. (eds.). Zagreb, pp. 71-77.

4. Jussila, J.; Raitanen, J.; Partanen, A.; Tuomela, V.; Siipola, V.; Kunnari, I., 2020: Rapid Product Development in University-Industry Collaboration: Case Study of a Smart Design. Technology Innovation Management Review, 10 (3): 49-59. http://doi.org/10.22215/timreview/1336.

5. Menichinelli, M.; Bianchini, M.; Maffei, S., 2020: Open and Distributed + Design and production. Design Strategies for Enabling Indie Designers and Makers. Strategic Design Research Journal, 13 (1). http://doi.org/10.4013/sdrj.2020.131.01.

6. Montresor, S.; Vezzani, A., 2019: Design centrality, design investments and innovation performance: an empirical analysis of European firms. Industrial and Corporate Change. https://academic.oup.com/icc/advance-article/ doi/10.1093/icc/dtz046/5553057 (Accessed Sep. 2, 2020).

7. Mulder-Nijkamp, M., 2020: Bridging the gap between design and behavioral research: (Re)searching the optimum design strategy for brands and new product innovations. Creativity and Innovation Management. https:// onlinelibrary.wiley.com/doi/abs/10.1111/caim.12393 (Accessed Sept. 2, 2020).

8. Naik, H. S.; Fritzsche, A.; Moeslein, K. M., 2020: Modularity in making: simplifying solution space for user innovation. R\&D Management. https://onlinelibrary.wiley. com/doi/abs/10.1111/radm.12427 (Accessed Sept. 2, 2020).

9. Norman, D. A., 2010: The Design of Everyday Things. $\mathrm{PhD}$ Thesis, Prague, Czech Republic (in Czech).

10. Parsons, T., 2009: Thinking Objects: Contemporary Approaches to Product Design. AVA Publishing, Switzerland.

11. Rzeszotarska-Palka, M.; Czalczynska-Podolska, M., 2019: Taming the urban space. IOP Conference Series:
Materials Science and Engineering, pp. 471. https://iopscience.iop.org/article/10.1088/1757899X/471/9/092045 (Accessed Sept. 3, 2020).

12. Verganti, R.; Vendraminelli, L.; Iansiti, M., 2020: Innovation and Design in the Age of Artificial Intelligence. Journal of Product Innovation Management, 37 (3): 212227. https://doi.org/10.1111/jpim.12523.

13. Vuković, A., 2018: Park user's preferences for wood equipment in Croatia and Slovenia. Master thesis, University of Zagreb, Faculty of Forestry, Zagreb (in Croatian).

14. Weinschenk, S. 2012: 100 Things Every Designer Needs to Know About People. Brno, Computer Press (in Czech).

15. Xihui, S. L.; Rieple, M. A., 2019: Design Management Capability in Entrepreneurship: A Case Study of Xiaomi. International Journal of Design, 13 (3): 125-138.

16. Yücel, G. F., 2013: Street furniture and amenitie: Desinging the User-Oriented Urban Landscape, Chapter 23. In: Advances in Landscape Architecture, Özyavuz, M. (ed.). IntechOpen, London, pp. 623-644. https://doi.org/10.5772/55770.

17. Zbiejczuk Sucha, V.; Kocourek, J.; Ondraskova, M.; Kalisek, P., 2017. 100 metod (100 methods). Development fund of Masaryk University in Brno. https://100metod.cz/ (Accessed Sept. 3, 2020).

18. ***WEB 1, 2013: The Standards ČSN, EN 2013: Information system oriented on furniture processing (online). Mendel University Brno. http://www.n-i-s.cz/cz/normycsn-en/page/30/ (Accessed Feb. 18, 2019).

19. ${ }^{* * *}$ WEB 2: Semigoods Company. Available at: https:// www.semigoods.com/; https://www.semigoods.com/collections/rian-rta-collection (Accessed Feb. 18, 2019).

20. ***WEB 3, mmCité: Bohém. https://www.mmcite.com/ bohem (Accessed Ap. 16, 2021).

21. ***WEB 4, Archiproducts: ARKI-BENCH | Bench By Pedrali. https://www.archiproducts.com/en/products/pedrali/modular-bench-with-solid-laminate-seat-and-oaklegs-arki-bench-bench_498615 (Accessed March. 14, 2021).

\section{Corresponding address:}

\section{SARAH SZÖKEOVÁ}

University in Brno

Faculty of Forestry and Wood Technology

Department of Furniture, Furniture Design and Habitation

Zemědělská 3, 603 00, Brno, CZECH REPUBLIC

e-mail: szokeova.sarah@gmail.com 